\title{
Influence of Exhaust Gas Recirculation on Dairy Scum Biodiesel Operated Diesel Engine Performance
}

\author{
Manjunath Channappagoudra ${ }^{1 *}$, K. Ramesh ${ }^{1}$, G. Manavendra ${ }^{2}$ \\ ${ }^{1}$ Department of Studies in Mechanical Engineering, University B.D.T College of Engineering, Davangere, Karnataka, \\ INDIA \\ ${ }^{2}$ Departments of Mechanical Engineering, B.I.E.T, Davangere, Karnataka, INDIA
}

*Corresponding Author: manjunath6729@gmail.com

Citation: Channappagoudra, M., Ramesh, K. and Manavendra, G. (2019). Influence of Exhaust Gas Recirculation on Dairy Scum Biodiesel Operated Diesel Engine Performance. European Journal of Sustainable Development Research, 3(1), em0064. https://doi.org/10.20897/ejosdr/3915

Published: February 6, 2019

\begin{abstract}
Effort towards prospective utilization of dairy waste scum oil methyl ester (DSOME) is extremely pronounced as a promising sustainable unconventional fuel for diesel engine as they have intrinsic oxygen content emits less HC and CO emission and contradictorily increases the NOx. In this regard, the present study elucidates the influence of engine exhaust gas recirculation (EGR) on diesel engine performance, combustion and emission characteristics operated with DSOME-B20 (20\% dairy scum biodiesel, by volume). The brake thermal efficiency (BTE) and brake specific fuel consumption (BSFC) are appreciably improved for 5\% and 10\% EGR in comparison with 15\% EGR rate. Mainly, about $49-57 \%$ of NOx can be reduced with 5-15\% EGR rate but increasing EGR rate more than 10\% dilutes the fresh intake air hence reduces the NOx and increases the HC, CO emissions. Hence use of $5-10 \%$ EGR in diesel engine is advantageous to get considerably improved performance and reduced HC, CO and NOx emissions.
\end{abstract}

Keywords: dairy scum oil methyl ester, exhaust gas recirculation, emission, combustion, oxides of nitrogen, diesel engine

\section{INTRODUCTION}

Diesel engines are reliable, cost effectiveness and greater efficient since extensively used, whereas they generate harmful NOx and soot emissions. Biodiesels exhibits the lower emissions than petroleum diesel, in this view biodiesel and ethanol fuels are the prominent alternative to replace petroleum diesel (Tutak et al., 2017; Channappagoudra et al., 2013). Biodiesel, diethyl ether (DEE), ethanol and methanol blending with petroleum diesel would reduce the HC, CO and soot emissions (Srihari et al., 2017). Different sources of biofuel production are available, among which activated sludge which is enriched with the nutrient such as nitrification-involved process which could be also a viable source for biofuel generation (Sepehri and Sarrafzadeh, 2018). In this aspect, dairy waste water can be used to produce the biodiesel. Hence, production cost and disposal problem can be reduced by producing biodiesel from dairy waste scum as the waste scum is available freely and abundantly in the milk dairies. The properties of dairy waste scum biodiesel are within ASTM limits hence it is promising substitute to the conventional diesel (Sivakumar et al., 2011; Yatish et al., 2016; Srikanth et al., 2017).

The NOx and PM (particulate matter) emission of the diesel engines is relatively greater and controlling of these with after treatment device like selective catalytic reduction, particulates filters and NOx storage catalyst in vehicles will complicated and expensive. EGR with throttle system can be used instead of after treatment devices with less cost (Ma et al., 2014). EGR application is the attractive method to reduce the NOx of light duty engines, 
whereas EGR in engine will increase the HC and CO emissions hence optimum EGR with biodiesel will be the feasible solution (Saleh, 2009). Use of EGR with low pressure (LP EGR) will be the attractive when compared to conventional high pressure EGR (HP EGR) in diesel engine (Giorgio and Massimo, 2013). EGR reduces the mean charge temperature, heat transfer rate and extends the combustion duration at examined condition which could improve the fuel economy. Hence, it is promised to improve the HCCI combustion (Fathi et al., 2011). Diesel engine with EGR operation reduces the NOx emission, in-cylinder pressure and heat release rate (HRR) in premixed combustion phase. Whereas it increases the smoke, HC, CO emissions and particulate matter because of bulk quenching, fuel impingement and over-mixing, leading too lean combustion (Zhu et al., 2011; Kiplimo et al., 2012; Can et al., 2016; Li et al., 2017; Thangaraja and Kannan, 2016). Palm biodiesel with EGR operation has shown the reduced output power, engine torque and increased fuel consumption. However, higher NOx of biodiesel can be controlled with EGR application (Hafizil et al., 2015). The HC, CO emissions are less and NOx is higher for biodiesel blends operated engine. This higher NOx emission can be controlled by using EGR technique with optimum EGR rate, but this increases the HC, CO emissions (Sakhare et al., 2016; Daniel et al., 2016; Daniel et al., 2015). At 15\% EGR, cylinder pressure and HRR are higher for biodiesel when compared to diesel fuels (Anandavelu et al., 2011; Gowthaman et al., 2015). EGR application has shown the improvement in fuel consumption, thermal efficiency and reduced heat loss hence it is considered to be most effective in diesel engine operation (Abd-Alla et al., 2002).

\section{Scope of the Present Study}

To replace the petroleum fuels research is going on and putting a lot of effort to develop alternative fuels for engine which are sustainable, eco friendly, cost effective, indecency on fossil fuels and which having comparable properties as that of petro-diesel. The biodiesel derived from any bio-origin can give the feasible solution for the problem associated to petroleum diesel fuel. Mainly, treating of dairy waste scum into fuel would be the value added benefit for the milk dairies in terms of economics, solution to disposal problem, mitigation of global warming and independency on fossil fuels. Biodiesel produced from milk dairy waste scum has more attention as it is available in huge quantity and emits lesser emission effects on ecosystem. In many countries pollution control norms are restricting to use the diesel engine as they emit more harmful emissions. Therefore, it is a major challenge for both manufacturer and user of diesel engine even they have better power output, thermal efficiency, durability and reliability. The major drawbacks of diesel engines are higher NOx emission and particulate matter. In this view, a lot of scope is there to minimize these emissions with various methods and techniques. The current experiment address the influence of EGR on diesel engine performance, combustion and emission characteristics fueled with dairy scum biodiesel.

\section{MATERIALS AND METHODOLOGY}

\section{Biodiesel Production}

Turbid white color and semisolid dairy waste scum is collected from milk diary effluent treatment unit and it is heated up to $50-60^{\circ} \mathrm{C}$ to convert it into liquid and permitted to settle down to remove lower aqueous phase. Upper layer of oil is separated, centrifuged and filtered to remove unwanted waste particles.

Flow diagram of biodiesel production process is demonstrated in Figure 1. Diary scum oil, methanol and potassium hydroxide are raw materials used for biodiesel production. The separated and filtered scum oil is processed through transesterification method. The scum oil, methanol and $\mathrm{KOH}$ (potassium hydroxide) are mixed well in a transesterification reactor at $60^{\circ} \mathrm{C}$ for two hours with aid of stirrer and allowed to be kept for twelve hours to separate biodiesel and glycerin, later obtained glycerin is taken off in a tank. Separated biodiesel is then washed three times with water to remove acids, soaps and residual catalyst. At the end biodiesel is heated to $110^{\circ}$ C to remove moistures from it.

\section{Biodiesel Properties}

Right fuel with right proration and slight engine modification may helps in getting better usage of fuel in engine. In this regard transesterified dairy scum biodiesel with $20 \%$ blend proportion (by volume) is considered for experimental investigations. The properties of DSOME and blends such as viscosity, heating value, density and flash point are determined as per ASTM- 6751 standards. Table 1 shows the properties of biodiesel blends. The Hydrometer is used to measure the density of the biodiesel and its blend. The flash points of the samples are measured by using Pensky-Martens closed-cup apparatus in $40-250{ }^{\circ} \mathrm{C}$ temperature range. The calorific value of biodiesel and its blends is measured in a Bomb Calorimeter as per ASTM standards. Viscosity of the test fuel is measured by using Redwood viscometer at a $40{ }^{\circ} \mathrm{C}$ temperature. 


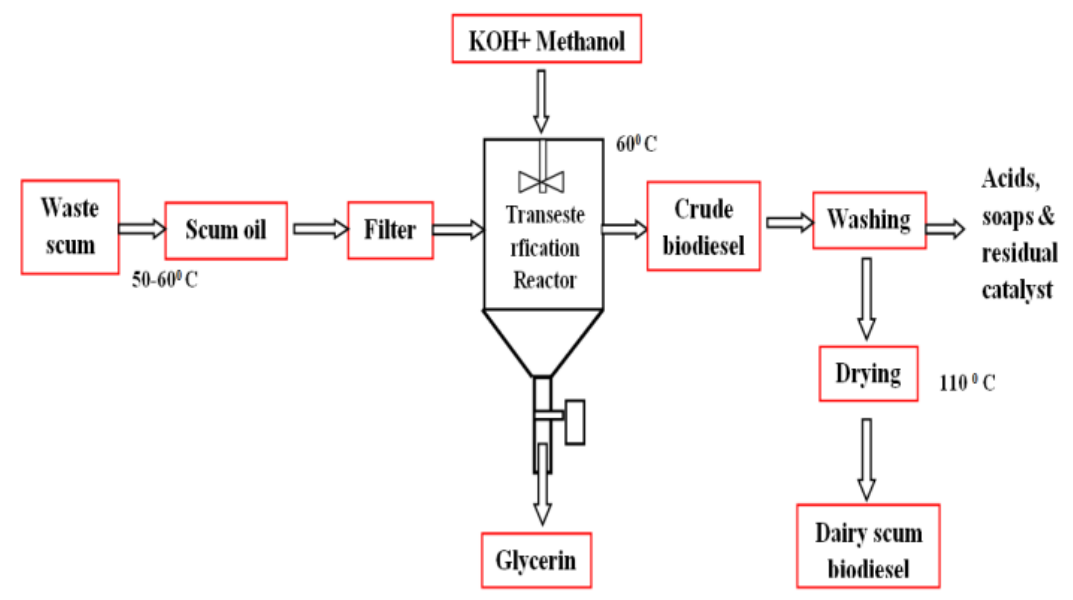

Figure 1. Process of biodiesel production

Table 1. Properties of biodiesel blends

\begin{tabular}{lcccc}
\hline Properties & $\begin{array}{c}\text { Methods } \\
\text { IS 1448 }\end{array}$ & Diesel & $\begin{array}{c}\text { DSOME } \\
\text { B20 }\end{array}$ & $\begin{array}{c}\text { DSOME } \\
\text { B100 }\end{array}$ \\
\hline Density $\left(\mathrm{kg} / \mathrm{m}^{3}\right)$ & $\mathrm{P}: 16$ & 830 & 840 & 870 \\
\hline Viscosity at $40^{\circ} \mathrm{C}(\mathrm{cSt})$ & $\mathrm{P}: 25$ & 2.9 & 2.98 & 4.36 \\
\hline Calorific value $(\mathrm{kJ} / \mathrm{kg})$ & $\mathrm{P}: 6$ & 43000 & 40890 & 38012 \\
\hline Flash Point $\left({ }^{\circ} \mathrm{C}\right)$ & $\mathrm{P}: 69$ & 50 & 58 & 130 \\
\hline Fire point $\left({ }^{\circ} \mathrm{C}\right)$ & - & 60 & 68 & 142 \\
\hline
\end{tabular}

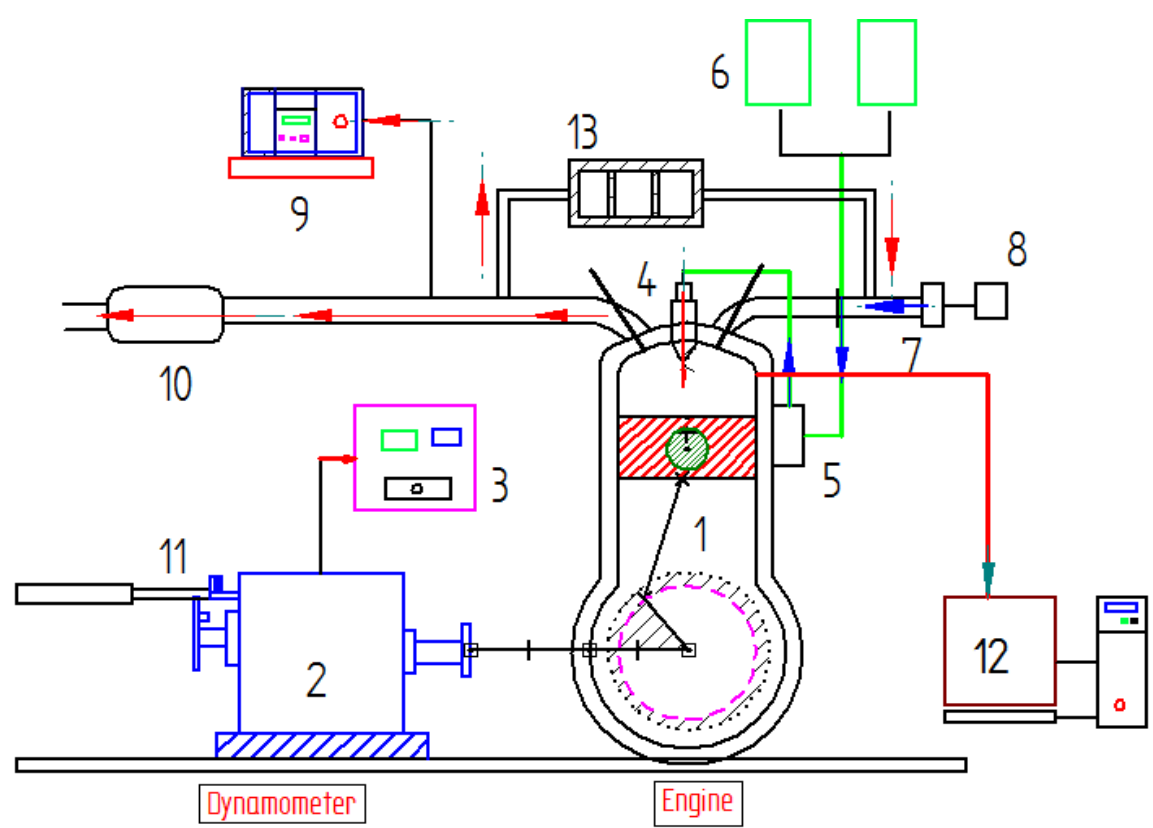

Figure 2. Schematic diagram of engine test rig

\section{Experimental Test Setup}

TV1 kirloskar diesel (Figure 2) is used to carry out the experiments and engine specifications are given in Table 2. The engine is connected with an eddy current dynamometer to vary the loads. The air flow rate is determined using orifice plate which is fitted to the air box. To prevent the overheating of the dynamometer, water circulation is provided. Rotameters are used to calculate the flow rate of water and thermocouples (K-Type) are used to measure the temperatures of water and exhaust gas. "Engine soft LV" software with Piezosensor and crank angle sensor is applied for online combustion examination. The baseline results are drawn with neat diesel operation. Then further experiments are carried by fueling DSOME-B20 at constant engine speed of $1500 \mathrm{rpm}$ and average of three readings is considered for the examination. Airrex Automotive Emission Analyzer HG-540 is used to determine the exhaust emissions, such as Hydrocarbons (HC), Carbon Monoxide (CO), and Oxides of Nitrogen (NOx). 
Table 2. Engine specifications

\begin{tabular}{ll}
\hline Parameters & Specifications \\
\hline Engine suppliers & Apex Innovations Pvt. Ltd \\
\hline Type & TV1 (Kirloskar) \\
\hline Cubic capacity & $661 \mathrm{cc}$ \\
\hline Bore and stroke length & $87.5 \mathrm{~mm} \mathrm{X} 110 \mathrm{~mm}$ \\
\hline Injector opening pressure & $210 \mathrm{bar}$ \\
\hline Rated power & $3.5 \mathrm{~kW}$ at $1500 \mathrm{rpm}$ \\
\hline Injection timing & $23^{\circ} \mathrm{bTDC}$ (diesel) \\
\hline No. of cylinder/stroke & one / four \\
\hline Cooling & water \\
\hline Compression ratio & 17.5 \\
\hline Dynamometer & Eddy current \\
\hline Software used & Engine soft
\end{tabular}

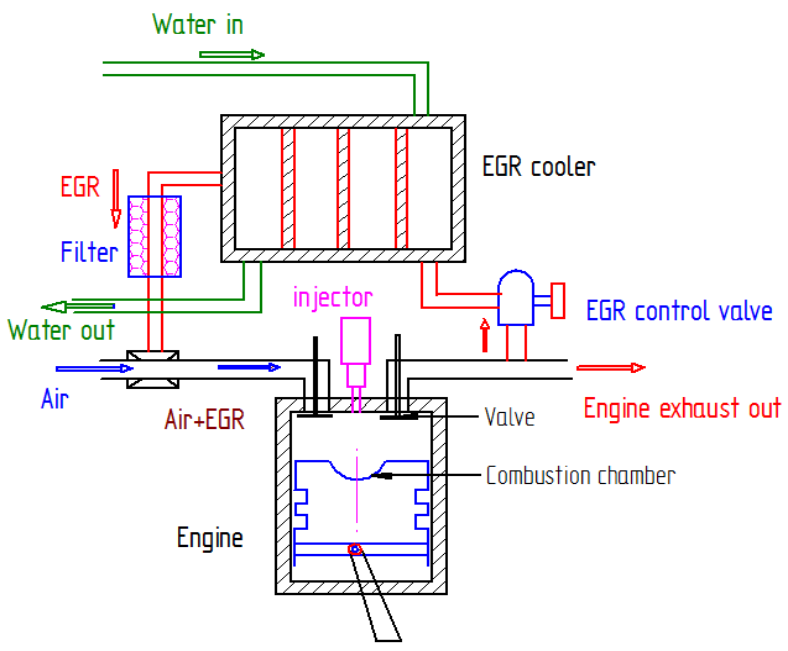

Figure 3. EGR arrangement in engine

1. Kirloskar TV1 engine, 2. Eddy Current Dynamometer 3. Control Panel, 4. Injector, 5. Pump, 6. Diesel and biodiesel tanks, 7. Air stabilizing tank, 8. Air filter, 9. Exhaust gas analyzers, 10. Exhaust gas silencer, 11. Crank encoder, 12. Data acquisition system, 13. EGR arrangement (schematic diagram shown in Figure 3).

\section{EGR Arrangement in Diesel Engine}

EGR arrangement (as shown in Figure 3) is used to control the NOx emissions. The exhaust gas from exhaust manifold is passed into air intake manifold through a heat exchanger (or EGR cooler-for cooling exhaust gas by water) and filter (for particulate removal). In which water is used as a cooling media in the heat exchanger. EGR valve is used to control of the flow rate of EGR at different ratios such as 5\%,10\% and $15 \%$ which are mixed with a clean air in the inlet manifold. And they are named as EGR 5\% $(24.7 \mathrm{~kg} / \mathrm{hr}$ air $+1.3 \mathrm{~kg} / \mathrm{hr}$ EGR), EGR 10\% $(23.4 \mathrm{~kg} / \mathrm{hr}$ air $+2.6 \mathrm{~kg} / \mathrm{hr}$ EGR $)$ and EGR $15 \%(22.1 \mathrm{~kg} / \mathrm{hr}$ air+3.9 kg/hr EGR) respectively. The EGR mass flow rate is the ratio of recirculated exhaust mass flow rate to the total mass flow rate allowed to enter into the engine (Saleh et al.; Zamboni et al.; Thangaraja et al.; Net et al.).

$$
\mathrm{EGR} \%=\frac{(\text { Mass or Volume of air without EGR })-(\text { Mass or volume of air with EGR })}{\text { (Mass or volume of air without EGR })}
$$

The study aims to find the best percentage of EGR and also intends to compare the performance, combustion and emission characteristics of diesel engine operated with Diesel, DSOME-B20 and DSOME-B20 with and without EGR.

\section{RESULTS AND DISCUSSION}

The exhaust gas is recirculated through inlet manifold of the Kirloskar diesel engine fueled with diary scum biodiesel. The performance (BTE, BSFC), combustion (peak pressure, HRR, CHRR and pressure rise) and emission characteristics ( $\mathrm{HC}, \mathrm{CO}$ and $\mathrm{NOx}$ ) of the engine diesel engine are determined and compared with neat diesel. The experiments are conducted at different loads like $0 \%, 20 \%, 40 \%, 60 \%$ and $100 \%$. 


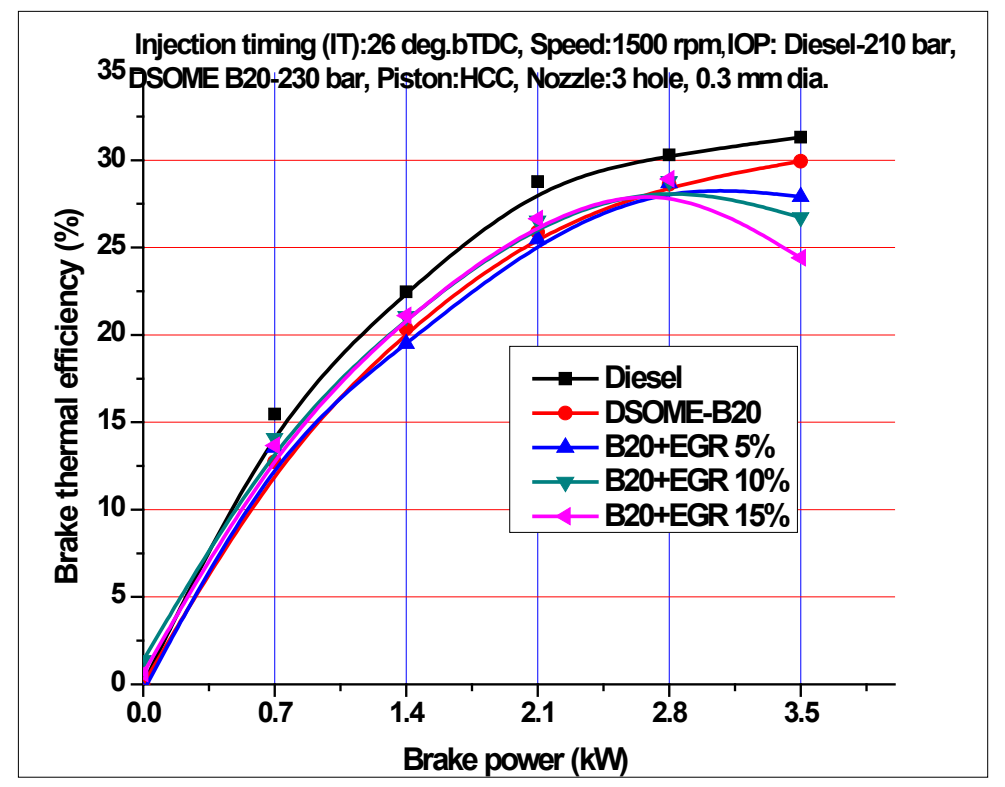

Figure 4. Variation of brake thermal efficiency versus brake power

\section{Performance Characteristics}

\section{Brake Thermal Efficiency}

Figure 4 demonstrates the variations of the brake thermal efficiency (BTE) versus brake power for diesel, DSOME-B20 and different EGR fractions like 5\%,10\% and 15\%. BTE is improved when the EGR is supplied to engine operated with DSOME-B20 at 80\% load. Whereas at 100\% load BTE is reduced for 10\% and $15 \%$ EGR. It could be attributed to introduction of more EGR into the combustion chamber leading to reduction in the amount of the air and DSOME-B20 fuel, since more dilution effect (displacement of oxygen intake) reduces the HRR and cylinder pressure therefore causing the incomplete combustion. The diesel fuel has higher BTE for entire load range when compared to other EGR concentrations; this could be attributed to superior calorific value and lower viscosity of diesel. At 80\% load BTE for Diesel, DSOME-B20, B20+EGR5\%, B20+EGR10\% and B20+EGR15\%, are 30.3\%, 28.61\%, 28.7\%, 28.79\%, 28.89\% and $28.92 \%$, respectively. At 100\% load, BTE is dropped for $5 \%, 10 \%$ and $15 \%$ EGR rates of $27.9 \%, 26.72 \%$ and $24.41 \%$ respectively. This could be attributed to the exhaust gas dilution of fresh air and increased specific heat leads to poor combustion (Fathi et al., 2011; Zhu et al., 2011; Yasin et al., 2015; Sakhare et al., 2016; Daniel et al., 2016; Anandavelu et al., 2011). As the EGR percentage increased more than $10 \%$, the BTE is decreases. This could be attributed to reduced fuel burning rate and higher diluted charge leads to reduction in oxygen content for combustion causing sluggish oxidation process and burning leads to poor combustion. 10\% EGR shows the better BTE at $80 \%$ load compare to other concentrations.

\section{Brake Specific Fuel Consumption}

Brake specific fuel consumption (BSFC) shows how efficiently engine utilizes the fuel to produce the brake power. The variation in BSFC with brake power for Diesel, DSOME-B20 and with exhaust EGR rate is represented in Figure 5. As the EGR percentage increased, the BSFC increased; the reason may be dilution of clean air with exhaust gas resulting poor combustion. It is observed that BSFC for DSOME-B20 fuel is higher for entire load range in comparison with diesel; it could be due to higher calorific value and lower viscosity of the petroleum diesel since more mass of fuel rate is required to generate same power as of diesel (Can et al., 2016). The BSFC is increased with increasing EGR percentage. This could be due to dilution of clean air with engine exhaust gas leads poor oxidation, combustion and lower output power hence more fuel is introduced to produce the same output power as of that diesel fuel (Fathi et al., 2011; Daniel et al., 2016; Gowthaman et al., 2015). From the results, it can be seen that BSFC for 10\% EGR is lower and nearer to diesel BSFC when compared to 5\% and $15 \%$ EGR for entire loads. This might be due to burning of fresh air and producing more heat release in the premixed combustion phase. In case of 15\% EGR, more dilution affects the intake fresh air because of poor combustion; hence it requires more fuel for combustion. The BSFC values for Diesel, DSOME-B20, 5\% EGR, $10 \%$ EGR and $15 \%$ EGR are $0.3,0.34,0.31,0.31$ and $0.32 \mathrm{~kg} / \mathrm{kW} . \mathrm{hr}$ respectively at $80 \%$ load. 


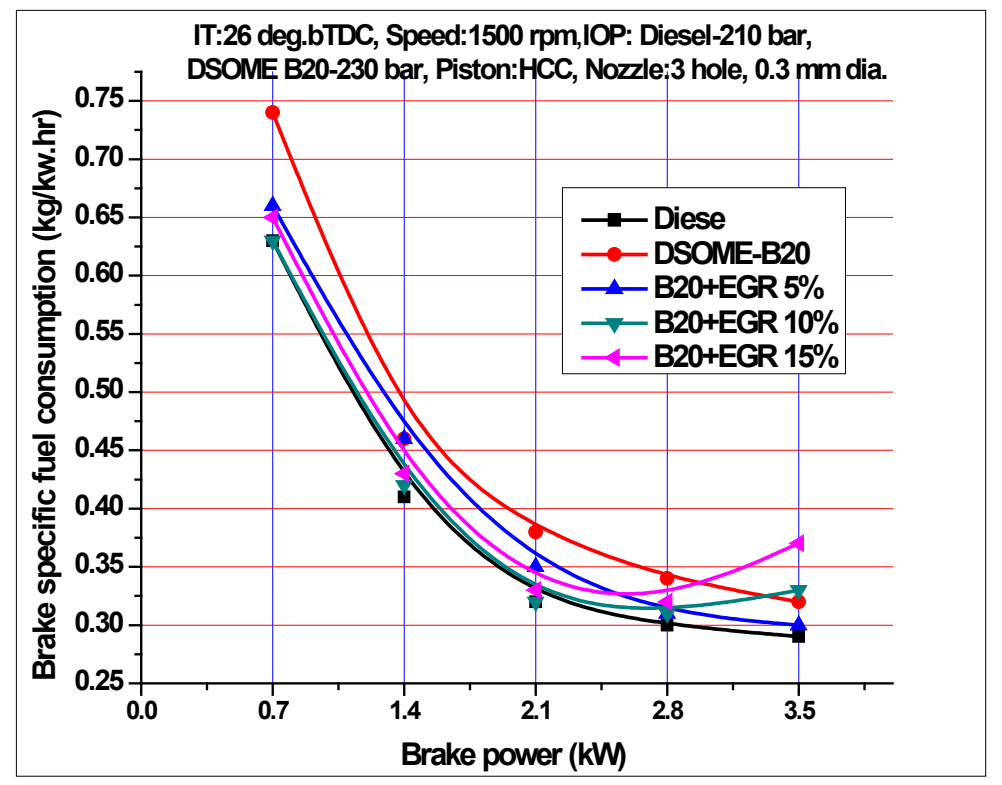

Figure 5. Comparison of brake specific fuel consumption against brake power

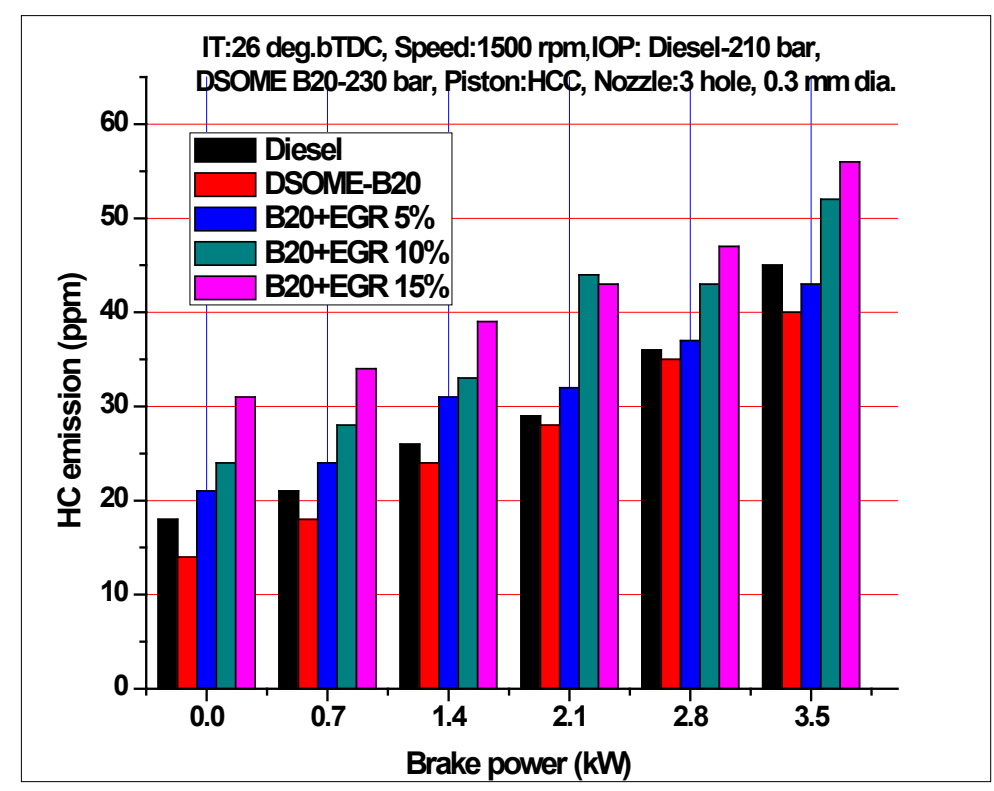

Figure 6. HC emission versus brake power

\section{Emission Characteristics}

\section{Hydrocarbon Emission}

Figure 6 depicts the deviation of HC emission with brake power for different EGR concentrations. The HC emission is increased with increased brake power. It is monitored that HC emission for DSOME-B20 is lower compare to conventional diesel as the biodiesel has more oxygen content will improves the oxidation process and combustion. The HC emission is increased with increased percentage of EGR in DSOME-B20 as there is dilution in the intake fresh air and over lean regions in combustion process (Can et al., 2016). HC is increased from $35 \mathrm{ppm}$ to $68 \mathrm{ppm}$ at $80 \%$ load and $40 \mathrm{ppm}$ to $76 \mathrm{ppm}$ at $100 \%$ load when the engine operation is switched from DSOMEB20 to DSOME-B20+15 EGR. Unfortunately, an HC emission is increased at higher levels of EGR rate which indicates the poor combustion quality. 


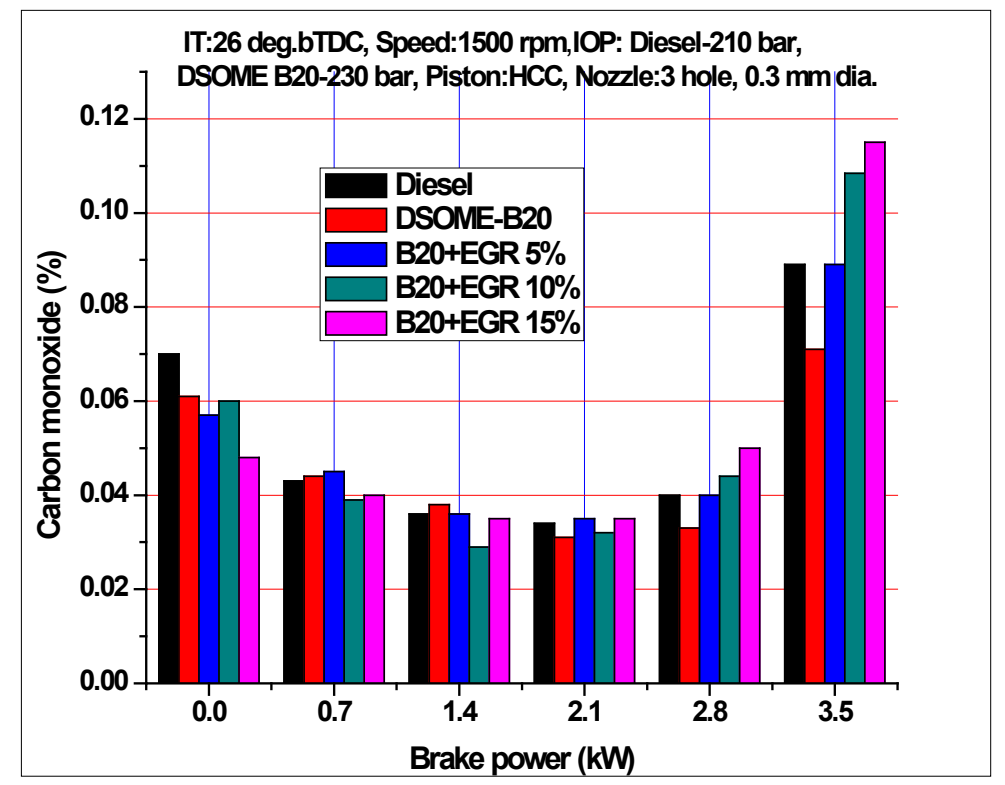

Figure 7. $\mathrm{CO}$ emission versus brake power

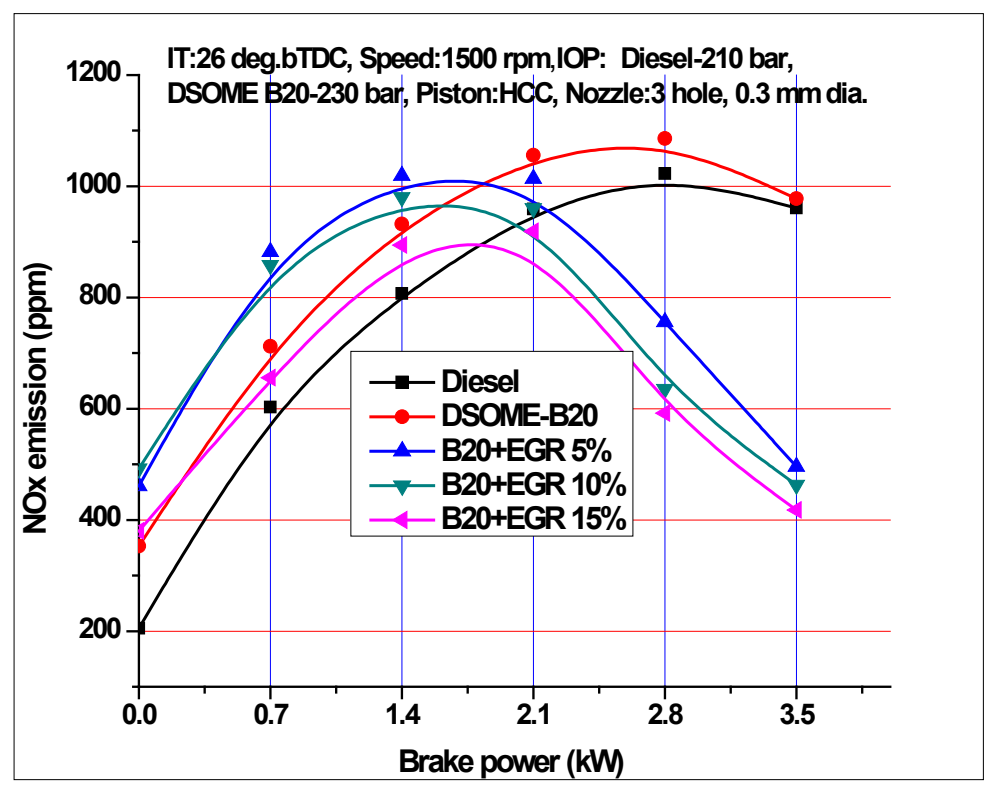

Figure 8. NOx emission versus brake power

\section{Carbon Monoxide Emission}

Figure 7 represents the distinction CO emissions with brake power for Diesel, DSOME-B20 and EGR concentrations. The test results shown that, CO emission of DSOME-B20 is lesser in comparison with petroleum diesel. This may be due to their inherent oxygen content in the biodiesl during combustion may convert carbon monoxide into carbon dioxide hence results the lower CO emissions (Gopal and Karupparaj, 2015; Raheman et al. 2013; Aydin and Bayindir, 2010; Sharon et al., 2012; Channappagoudra et al., 2018a; Channappagoudra et al., 2018b). As the EGR percentage is increased the CO emission is also increased, it could be attributed to higher dilution in the intake air results lower cylinder temperature. At $80 \%$ and $100 \%$ load, the CO emission is increased at 15\% EGR. It may attribute to poor burning as the increased EGR rate and lesser oxidation temperature (Can et al., 2016) reduce the oxygen supply. The experimental results for diesel, DSOME-B20, EGR\%, EGR10\% AND EGR $15 \%$ are $0.04,0.037,0.087,0.136$ and $0.337 \%$ at $80 \%$ load and $0.089,0.076,0.296,0.428$ and $0.58 \%$ at $100 \%$ load respectively. 


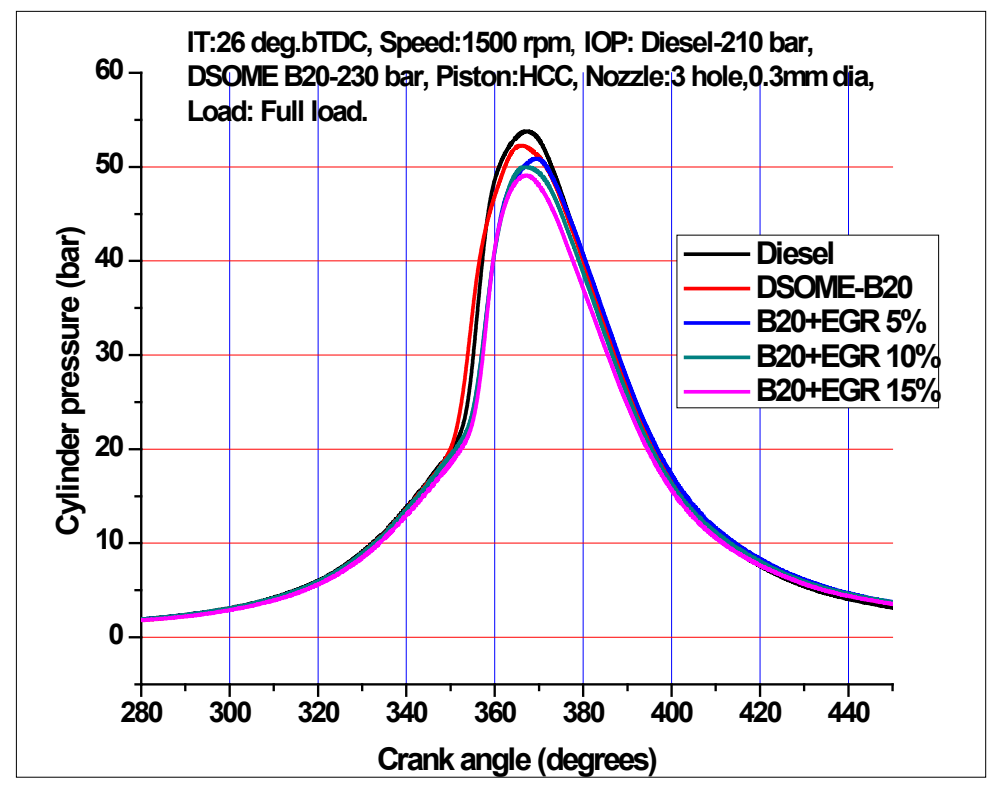

Figure 9. Cylinder pressure versus crank angle at full load

\section{Oxides of Nitrogen Emission}

Figure 8 shows the deviation of NOx emission with brake power. A main impediment to the wide utilization of conventional diesel engines is higher levels of NOx and particulate matter (PM) emissions. Because they have harmful smog and acid rain hence effects on the human health and environment (Daniel et al., 2016). In diesel engine, NOx emission is influenced by rich oxygen and flame temperature. As the load is increased, the NOx emission is increased. This could be due to increased cylinder temperature at higher injection of fuel at higher load. The NOx for DSOME-B20 is higher than the petroleum diesel and other EGR ratios. This might be due to increased quantity fuel injection leads to higher cylinder temperatures and HRR during premixed combustion hence cause in higher NOx emission (Saleh et al., 2009). It is also observed that, more NOx emission is occurs during lean mixture and when the EGR rate is least effective ( $\mathrm{Li}$ et al., 2017). At $80 \%$ load, NOx emission is reduced from $1086 \mathrm{ppm}$ to $635 \mathrm{ppm}$, at 100\% load NOx is reduced from $978 \mathrm{ppm}$ to $463 \mathrm{ppm}$ for B20+10\% EGR respectively. Similarly at $80 \%$ load NOx reduced from $1086 \mathrm{ppm}$ to $592 \mathrm{ppm}$, at 100\% load NOx reduced from $978 \mathrm{ppm}$ to $418 \mathrm{ppm}$ for B20+15\% ER. On average of both loads, $46 \%$ and $51 \%$ of NOx is reduced when engine is operated with 10\% and 15\% EGR. However, $15 \%$ of EGR-addition into engine illustrates a very inferior value of NOx when compared to other EGR ratios in diesel engine operation. This could be due to increased total heat capacity (specific heat) of the exhaust gases as they lowers the elevated temperature and cause the dilution of clean air. Therefore decreases the oxygen concentration thus leads to incomplete combustion and lesser cylinder temperature (Fathi et al., 2011; Zhu et al., 2011; Yasin et al., 2015; Sakhare et al., 2016; Daniel et al., 2016; Anandavelu et al., 2011).

\section{Combustion Characteristics}

\section{Cylinder Pressure}

Distinction of cylinder pressure with crank angle at maximum load fueled with Diesel, DSOME-B20 and different EGR ratios is shown in the Figure 9. DSOME-B20 has less trace of pressure waves and also the deviation of gas pressure hence causes the smooth running of the engine at full load. The cylinder pressure is highest with Diesel of 53.63 bar followed by DSOME-B20 of 52.29 (without EGR). The cylinder pressure decreases for the EGR concentrations when compared to DSOME-B20. This might be attributed to EGR application in the engine increases the ignition delay period hence amount of fuel burnt in the premixed combustion phase is less leads to more combustion duration or terrible fuel-air mixing cause incomplete combustion. In three ways, EGR influences the diesel engines combustion it is well explained by Zhu et al. (2011) and Ladommatos et al. (1998). Firstly, dilution mechanism: increases the time of fuel-air mixing and reduces the flame temperature; secondly, thermal mechanism: increases the EGR charge heat capacity leads decreased flame temperature: thirdly, chemical mechanism: enhanced dissociation of higher EGR molecules results lower flame temperature. The cylinder pressure values for 5\%,10\% and 15\% EGR are found to be 52.18, 49.97 and 49.14 bars respectively at maximum load. The cylinder pressure is increased upto 10\% EGR rate and drops for 15\% EGR rate. 


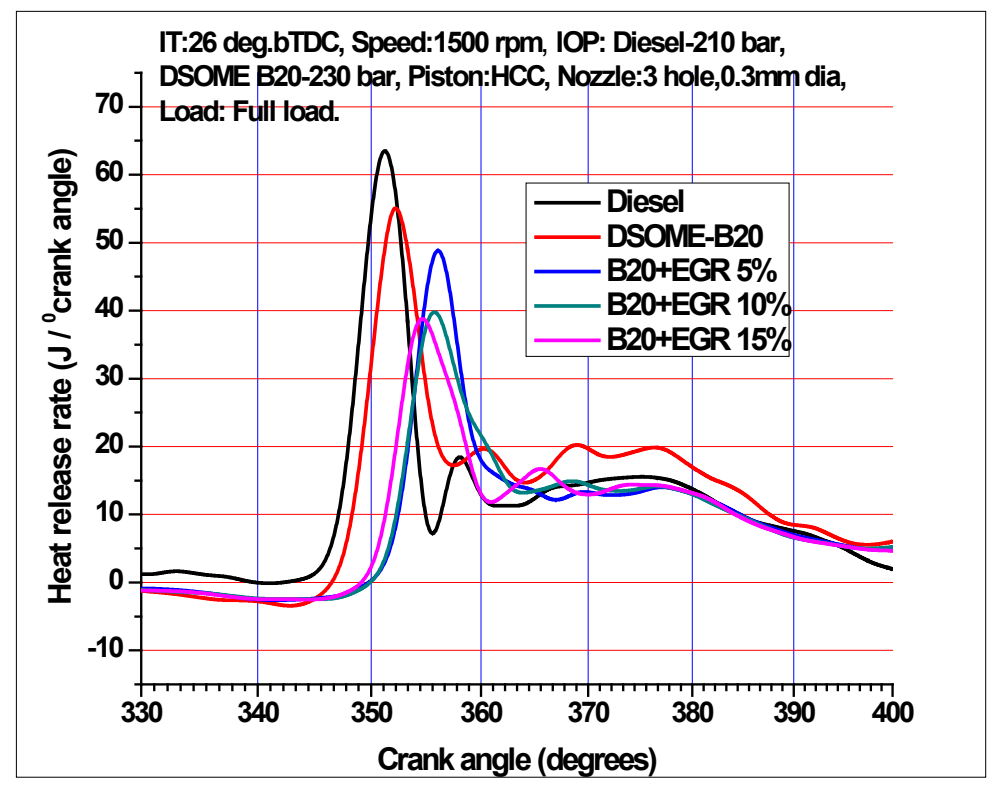

Figure 10. Heat release rate versus crank angle at maximum load

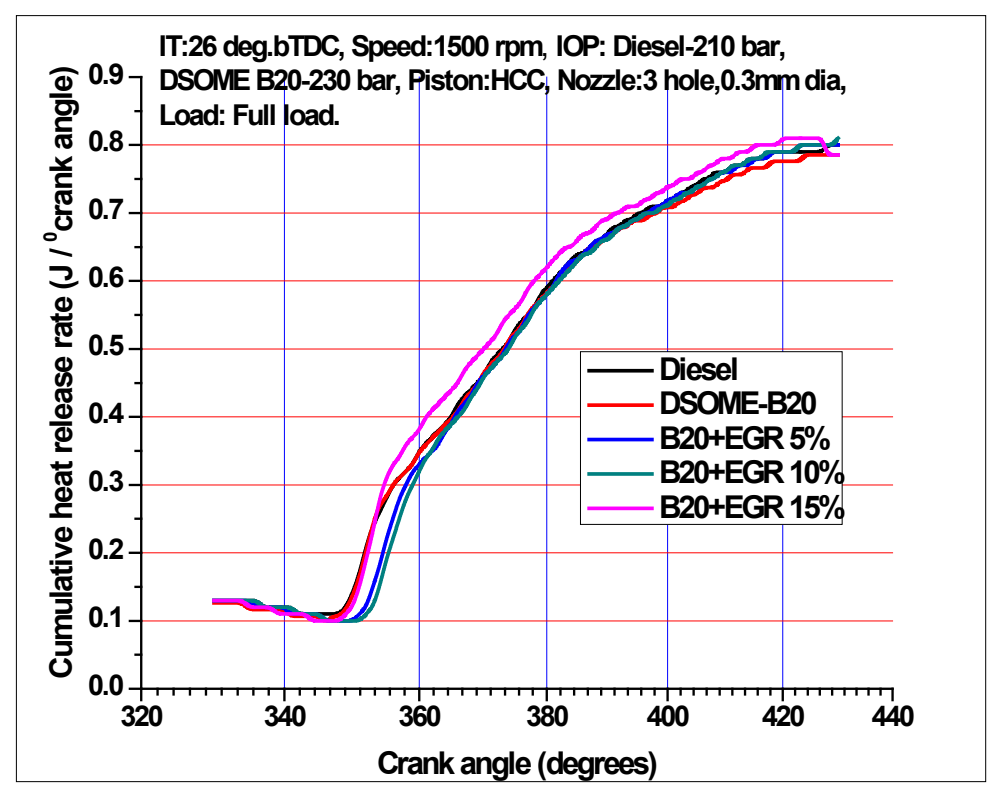

Figure 11. Cumulative heat release rate versus crank angle at full load

\section{Heat Release Rate}

The deviation of heat release rates (HRR) with Diesel and DSOME-B20 for different EGR rates at full load are demonstrated in Figure 10. Initially a slight negative heat release rate is monitored during ignition delay period. This might be due to cooling effect of vaporization of the DSOME-B20 blend and loss of heat from cylinder walls (Heywood, 1998). The HRR is higher for diesel fuel as it has higher calorific value and lesser viscosity leads to better air-fuel mixing and improved combustion. HRR is reduced with introduction of EGR, the reason could be lower in cylinder temperature caused by EGR dilution effect leads to longer ignition delay and retarded combustion phase (Giorgio and Massimo, 2013; Zhu et al., 2011; Kiplimo et al., 2012). EGR (exhaust gas as thermal sink) reduces the peak cylinder pressure and charge temperature during combustion by lowering the oxygen concentration, increased ignition delay in remixed combustion phase and reduced pressure rise rates (lower knocking) leads to lower heat release rate when compared to DSOME-B20 (Fathi et al., 2011). The HRR values for Diesel, DSOME-B20, 5\%, 10\% and 15\% EGR ratios are 65.43, 57.14, 50.87, 40.7 and 39.37J/crank angle respectively at full load. 


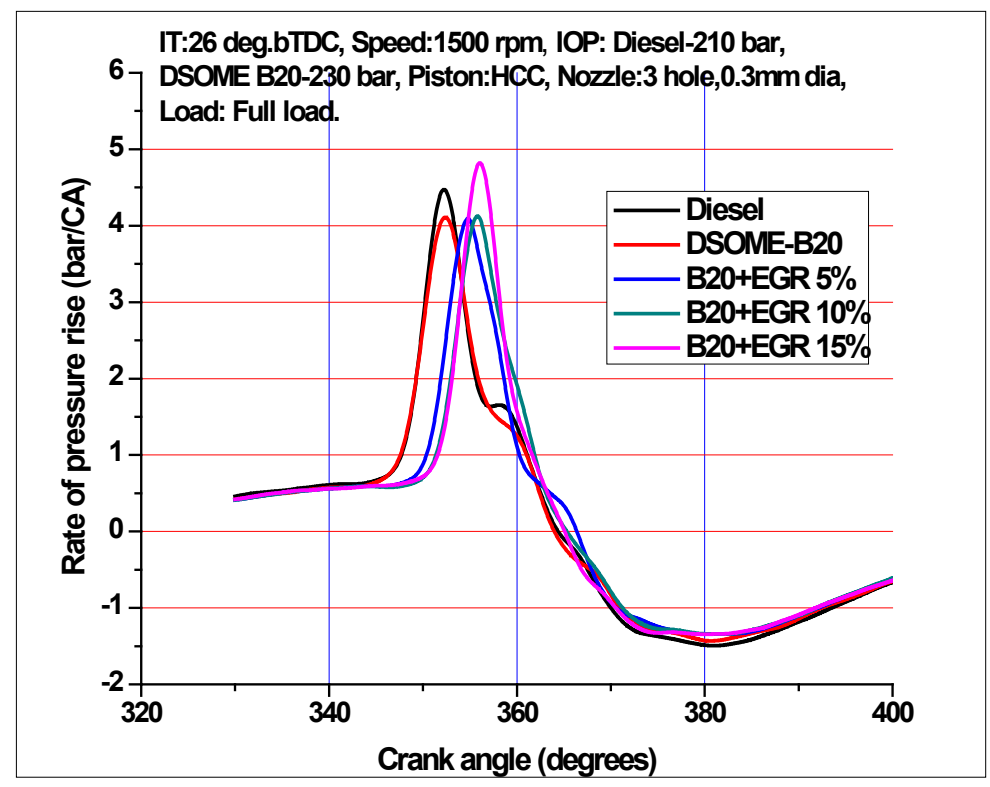

Figure 12. Rate of pressure rise versus crank angle at full load

\section{Cumulative Heat Release Rate}

Cumulative heat release (CHRR) versus crank angle is illustrated in Figure 11 for Diesel, DSOME-B20, and EGR concentrations. From the results, it is noticed that CHRR is increased at the later part of the combustion process for all blends. It might be due to liberation of more heat as the more quantity of fuel is introduced during combustion. At 15\% EGR after rapid combustion phase the temperature and pressure of the fuel droplets and cylinder gases are higher leads to higher CHHR than DSOME-B20. From the experimental results, it is found that diesel has highest CHRR ( $0.800 \mathrm{~J} /$ crank angle) than B20 fuel blend $(0.785 \mathrm{~J} /$ crank angle). The CHRR values for $5 \%, 10 \%$ and $15 \%$ are found to be $0.780,0.790$ and $0.810 \mathrm{~J} / \mathrm{crank}$ angle respectively at higher load.

\section{Pressure Rise Rate}

Pressure rise rate influences the peak cylinder pressure, power output and engine smooth running. The pressure rise rate depends on the amount of fuel-air mixture burning in the cylinder. From the graph, it is noticed that more time is required for lower rate of combustion whereas less time for faster combustion rate as they have shown higher pressure rise rate. The pressure rise rate versus crank angle for diesel, DSOME-B20 and different EGR concentrations at 100\% load is illustrated in Figure 12. The rate of pressure rise for DSOME-B20 is lower than $15 \%$ EGR, it might be due to greater viscosity, lower heating value and lower volatility of biodiesel leading to generate lower cylinder temperature and pressure waves in the combustion cavity during rapid combustion phase. When the EGR percentage is increased the rate of pressure rise is substantially elevated than that of sole DSOMEB20 (without EGR) it may be due to increased charge temperature and instantaneous burning of DSOME-B20 at higher EGR rate. After reaching the highest pressure, it falls progressively to lower levels during the expansion process. The pressure rise rate is higher for 15\% EGR when compared to 5\% and 10\% EGR it is attributed to increased temperature of charge before the flame front reaches cause auto ignition or detonation results rapid release of energy causing increased pressure of the gases inside the cylinder leads pressure rise in the cylinder. The rate pressure rise values for Diesel, DS0ME-B20, 5\%, 10\% and 15\% EGR are seen to be 4.6, 4.17, 4.23, 4.28 and 4.5 bars/ crank angle at full load.

\section{CONCLUSION}

A comprehensive examination made on diesel engine operated with Diesel and DSOME-B20 fuels. Study intended to examine the influence of EGR on diesel engine performance, combustion and emission characteristics.

1. From the study it is observed that, $5 \%$ and $10 \%$ EGR rates have shown the improved BTE, BSFC, HRR and cylinder pressure and reduced $\mathrm{HC}$ and $\mathrm{CO}$ than $15 \%$ EGR.

2. About $49-57 \%$ of NOx can be reduced with $5-15 \%$ EGR rate. Whereas increasing EGR rate more than $10 \%$, reduces the NOx but increases the $\mathrm{HC}$ and CO emissions at higher extent, the reason might be due 
to higher EGR rate dilutes the fresh intake air, hence reduces the combustion temperature, oxygen content, flame temperature and increases the dissociation of higher EGR molecules.

3. Therfore use of 5-10\% EGR in diesel engine is advantageous to get significantly improved performance and reduced $\mathrm{HC}, \mathrm{CO}$ and $\mathrm{NOx}$ emissions.

4. Application of EGR in diesel engine reduces the NOx emission meanwhile increases the HC and CO emissions. This is the conflict of EGR application in diesel engines. However, a 10\% EGR rate would be the suitable concentration when compared to $5 \%$ and $15 \%$ EGR flow rates.

\section{Scope for the future work}

The advantage of biodiesel is the more inherent oxygen content and lessr $\mathrm{HC}, \mathrm{CO}$ emissions whereas biodiesels emits the more NOx emission. The control of NOx using EGR there will be increment in HC and CO emission. This is the major conflict of the EGR. However study can be extend to reduce the NOx by using different methods like, water injection into cylinder, water emulsion, application of nanoadditives, slight engine modifications, use of catalytic converters etc.

\section{Acknowledgements}

The authors are grateful to I \& D (Information and Demonstration on Biofuels) Centre, Biofuel Park Madenur, Hasan which is sponsored by Karnataka State Biofuel Development Board (KSBD), Govt. of Karnataka (India) for providing dairy scum biodiesel for research work. Authors would like to acknowledge the Managing Director of Apex Innovations, Sangli (India) for providing computerized experimental test setup to conduct the experiments.

\section{ABBREVIATIONS}

$\begin{array}{ll}\text { ASTM } & \text { American Society for Testing and Materials } \\ \text { BTE } & \text { Brake Thermal Efficiency } \\ \text { BSFC } & \text { Brake Specific Fuel consumption } \\ \text { B20 } & (20 \% \text { Biodiesel + 80\% Diesel }) \\ \text { B100 } & (100 \% \text { Biodiesel }) \\ \text { CHRR } & \text { Cumulative Heat Release Rate } \\ \text { CO } & \text { Carbon Monoxide } \\ \text { CO } 2 & \text { Carbon Dioxide } \\ \text { DEE } & \text { Diethyl Ether } \\ \text { DSOME } & \text { Dairy Waste Scum Oil Methyl Ester } \\ \text { DSOME-B20 } & \text { (20\% Dairy Waste Scum Oil Methyl Ester }) \\ \text { DSOME-B100 } & (100 \% \text { Dairy Waste Scum Oil Methyl Ester }) \\ \text { EGR } & \text { Exhaust Gas Recirculation } \\ 5 \% \text { EGR } & (5 \% \text { EGR+ } 95 \% \text { Air) } \\ 10 \% \text { EGR } & (10 \% \text { EGR+ } 90 \% \text { Air }) \\ 15 \% \text { EGR } & (15 \% \text { EGR+ } 85 \% \text { Air }) \\ \text { HC } & \text { Hydrocarbon } \\ \text { HCCI } & \text { Homogeneous Charge Compression Ignition } \\ \text { HP } & \text { High Pressure } \\ \text { HRR } & \text { Heat Release Rate } \\ \text { KOH } & \text { Potassium hydroxide } \\ \text { LP } & \text { Low Pressure } \\ \text { NOx } & \text { Nitrogen oxide }\end{array}$

\section{REFERENCES}

Abd-Alla, G. H. (2002). Using exhaust gas recirculation in internal combustion engines: a review. Energy Conversion and Management, 43, 1027-1042. https:// doi.org/10.1016/S0196-8904(01)00091-7

Anandavelu, K., Alagumurthi, N. and Saravanan, C. G. (2011). Performance and emission studies on biofuel powered Kirloskar TV-1 direct-injection diesel engine with exhaust gas recirculation. International Journal of Sustainable Energy, 30(sup1), S66-S75. https://doi.org/10.1080/14786451.2011.590590

Aydin, H. and Bayindir, H. (2010). Performance and emission analysis of cottonseed oil methyl ester in a diesel engine. Renewable Energy, 35, 588-592. https://doi.org/10.1016/j.renene.2009.08.009 
Can, O., Ozturk, E., Solmaz, H., Aksoy, F., Cinar, C. and Yucesu, H. S. (2016). Combined effects of soybean biodiesel fuel addition and EGR application on the combustion and exhaust emissions in a diesel Engine. Applied Thermal Engineering, 95, 115-124. https://doi.org/10.1016/j.applthermaleng.2015.11.056

Channappagoudra, M. N., Thaned, S., Ramesh, K. and Manavendra, G. (2013). Optimization of Combustion Chamber Geometry for a Direct Injection Diesel Engine: A Review. International Journal of Engineering Research \& Technology (IJERT), ISSN: 2278-0181, 2(11).

Channappagoudra, M. N., Ramesh, K. and Manavendra, G. (2018a). Effect of Injector Opening Pressure on Dairy Scum Biodiesel Operated Diesel Engine. International Journal of Current Advanced Research, ISSN: O: 2319-6475, ISSN: P: 2319-6505, 7(4), 12151-12160. http://doi.org/10.24327/ijcar.2018. 12160.2131

Channappagoudra, M. N., Ramesh, K. and Manavendra, G. (2018b). Effect of Injection timing on diesel engine performance, combustion and emission characteristics operated with Dairy Scum Biodiesel. International Journal of Current Engineering and Technology, E-ISSN: 2277-4106, P-ISSN: 2347-5161. https://doi.org/10.14741/ijcet/v.8.3.5

Daniel, M. P., Kumar, K. V. and Prasad, B. D. (2016). Performance and emission characteristics of diesel engine operated on tyre pyrolysis oil with exhaust gas recirculation. International Journal of Ambient Energy, 37(6), 609615. https://doi.org/10.1080/01430750.2015.1023837

Daniel, M. P., Kumar, K. V., Prasad, B. D. and Puli, R. K. (2015). Performance and emission characteristics of diesel engine operated on plastic pyrolysis oil with exhaust gas recirculation. International joumal of ambient energy. ISSN: 0143-0750 (Print) 2162-8246 (Online).

Fathi, M., Saray, R. K. and Checkel, M. D. (2011). The influence of Exhaust Gas Recirculation (EGR) on combustion and emissions of $\mathrm{n}$-heptane/natural gas fueled Homogeneous Charge Compression Ignition (HCCI) engines. Applied Energy, 88, 4719-4724. https://doi.org/10.1016/j.apenergy.2011.06.017

Gopal, K. N. and Karupparaj, R. T. (2015). Effect of pongamia biodiesel on emission and combustion characteristics of DI compression ignition engine. Ain Shams Engineering Journal, 6, 297-305. https://doi.org/10.1016/j.asej.2014.10.001

Gowthaman, S. and Sathiyagnanam, A. P. (2015). The effect of exhaust gas recirculation on performance and emission characteristics of HCCI engine. International Journal of Ambient Energy, ISSN: 0143-0750 (Print) 21628246 (Online).

Heywood, J. B. (1988). Internal Combustion Engine Fundamentals, McGraw-Hill Series in Mechanical Engineering, 198.

Kiplimo, R., Tomita, E., Kawahara, N. and Yokobe, S. (2012). Effects of spray impingement, injection parameters, and EGR on the combustion and emission characteristics of a PCCI diesel engine. Applied Thermal Engineering, 37, 165-175. https://doi.org/10.1016/j.applthermaleng.2011.11.011

Ladommatos, N., Abdelhalim, S. M., Zhao, H. and Hu, Z. (1998). Effects of EGR on heat release in diesel combustion. SAE Tech Paper No. 980184. https:/ / doi.org/10.4271/980184

Li, B., Li, Y., Liu, H., Liu, F., Wanga, Z. and Wang, J. (2017). Combustion and emission characteristics of diesel engine fueled with biodiesel/PODE blends. Applied Energy, 206, 425-431. https://doi.org/10.1016/j.apenergy.2017.08.206

Ma, X., Zhang, F., Xu, H. and Shua, S. (2014). Throttleless and EGR-controlled stoichiometric combustion in a diesel-gasoline dual-fuel compression ignition engine. Fuel, 115, 765-777. https://doi.org/10.1016/j.fuel.2013.07.052

Raheman, H., Jena, P. C. and Jadav, S. S. (2013). Performance of a diesel engine with blends ofnbiodiesel (from a mixture of oils) and high-speed Diesel. International Journal of Energy and Environmental Engineering, 4(6). https://doi.org/10.1186/2251-6832-4-6

Sharon, H., Karuppasamy, K., Kumar, D. R. S. and Sundaresan, A. (2012). A test on DI diesel engine fueled with methyl esters of used palm oil. Renewable Energy, 47, 160-166. https://doi.org/10.1016/j.renene.2012.04.032

Sakhare, N. M., Shelke, P. S. and Lahane, S. (2016). Experimental Investigation of Effect of Exhaust Gas Recirculation and Cottonseed B20 Biodiesel Fuel on Diesel Engine. Procedia Technology, 25, 869-876. https://doi.org/10.1016/j.protcy.2016.08.195

Saleh, H. E. (2009). Effect of exhaust gas recirculation on diesel engine nitrogen oxide reductionoperating with jojoba methyl ester. Renewable Energy, 34, 2178-2186. https:// doi.org/10.1016/j.renene.2009.03.024

Sepehri, A. and Sarrafzadeh, M. H. (2018). Effect of nitrifiers community on fouling mitigation and nitrification efficiency in a membrane bioreactor. Chemical Engineering and Processing-Process Intensification, 128, 10-18. https://doi.org/10.1016/j.cep.2018.04.006

Sivakumar, P., Anbarasu, K. and Renganathan, S. (2011). Bio-diesel production by alkali catalyzed transesterification of dairy waste scum. Fuel, 90, 147-151. https:// doi.org/10.1016/j.fuel.2010.08.024

Srihari, S., Thirumalini, S. and Prashanth, K. (2017). An experimental study on the performance and emission characteristics of PCCI-DI engine fuelled with diethyl ether-biodiesel-diesel blends. Renewable Energy, 107, 440447. https://doi.org/10.1016/j.renene.2017.01.015 
Srikanth, H. V., Venkatesh, J., Godiganur, S., Venkateswaran, S. and Manne, B. (2017). Bio-Based Diluents Improve Cold Flow Properties of Dairy Washed Milk-Scum Biodiesel. Renewable Energy, 111, 168-174. https://doi.org/10.1016/j.renene.2017.03.092

Thangaraja, J. and Kannan, C. (2016). Effect of exhaust gas recirculation on advanced diesel combustion and alternate fuels - A review. Applied Energy, 180, 169-184. https://doi.org/10.1016/j.apenergy.2016.07.096

Tutak, W., Jamrozik, A., Pyrc, M. and Sobiepanski, M. (2017). A comparative study of co-combustion process of diesel-ethanol and biodiesel-ethanol blends in the direct injection diesel engine. Applied Thermal Engineering, 117, 155-163. https://doi.org/10.1016/j.applthermaleng.2017.02.029

Yasin, M. H. M., Mamat, R., Yusop, A. F., Paruka, P., Yusafb, T. and Najafi, G. (2015). Effects of Exhaust Gas Recirculation (EGR) on a Diesel Engine fuelled with Palm-Biodiesel. Energy Procedia, 75, 30 -36. https://doi.org/10.1016/j.egypro.2015.07.131

Yatish, K. V., Lalithamba, H. S., Suresh, R., Arun, S. B. and Kumar, P. V. Optimization of scum oil biodiesel production by using response surface methodology. Process Safety and Environmental Protection, 102, 667-672. https://doi.org/10.1016/j.psep.2016.05.026

Zamboni, G. and Capobianco, M. (2013). Influence of high and low pressure EGR and VGT control on in-cylinder pressure diagrams and rate of heat release in an automotive turbocharged diesel engine. Applied Thermal Engineering, 51, 586-596. https://doi.org/10.1016/j.applthermaleng.2012.09.040

Zhu, R., Wang, X., Miao, H., Yang, X. and Huang, Z. (2011). Effect of dimethoxy-methane and exhaust gas recirculation on combustion and emission characteristics of a direct injection diesel engine. Fuel, 90, 1731-1737. https://doi.org/10.1016/j.fuel.2011.01.035 